УДК 342.32

DOI https://doi.org/10.32837/npnuola.v26i0.664

H. B. мішина

\title{
ОРГАНИ САМООРГАНІЗАЦІЇ НАСЕЛЕННЯ В УКРАЇНІ: ТИПОЛОГІЯ ТА КЛАСИФІКАЦІЯ
}

\begin{abstract}
Постановка проблеми в загальному вигляді та її зв'язок із важливими науковими чи практичними завданнями. Муніципальна реформа в Україні зумовлює необхідність аналізу як досягнень, так і прорахунків. Особлива увага при цьому приділяється питанням залучення населення до здійснення місцевого самоврядування. Вагому роль у цьому процесі відіграють органи самоорганізації населення. Отже, важливим науковим завданням є критичний аналіз їхнього функціонування в Україні з метою формулювання пропозицій щодо подальшого вдосконалення законодавства в цій сфрері.

Саме органи самоорганізації шляхом активізації інтересу населення до місцевих справ, місцевих проблем і пошуку оптимальних шляхів їхього розв'язання сприяють підвищенню рівня громадської свідомості та подальшому розвитку громадянського суспільства в Україні. У зв'язку 3 цим уявляється доцільним звернути увагу на доктринальне забезпечення функціонування інституту самоорганізації населення. Уявляється, що розв'язання цих актуальних питань на науковому рівні сприятиме внесенню відповідних змін до законодавства України, що позитивно вплине на динаміку створення нових і ефективність функціонування чинних органів самоорганізації населення.
\end{abstract}

Аналіз останніх досліджень і публікацій, в яких започатковано розв'язання цієї проблеми і на які спирається автор, виділення не вирішених раніше частин загальної проблеми, яким присвячується стаття. Питання, пов'язані зі створенням і функціонуванням органів самоорганізації населення, не оминув увагою жоден фахівець із муніципального права України. Вагоме значення для дослідження цих органів, їхньої правової природи мають праці М.О. Баймуратова, О.В. Батанова, Б.В. Калиновського, П.М. Любченка, М.П. Орзіха та інших учених. Однак ці автори приділяли вкрай небагато уваги питанням типології та класифікації органів самоорганізації населення в Україні. Деякі напрацювання в цьому напрямі належать автору цієї статті (див.: [1-3]).

Під час написання статті використовувались праці В.С. Кашо, Б.М. Страшуна, Б.М. Габричідзе і О.К. Конєва, у яких вони розглядали 
аналоги сучасних органів самоорганізації населення в Україні, що існували в часи СРСР, - органи територіального громадського самоврядування. Незважаючи на те, що відповідний інститут у СРСР досліджувала велика кількість науковців, тільки в статтях і монографіях наведених вище авторів містяться положення щодо можливих підстав для класифікацій органів територіального громадського самоврядування.

Формулювання цілей статті. Мета статті - запропонувати шляхи типології та класифікації органів самоорганізації населення в Україні.

Матеріал дослідження. Автор уважає доцільним введення в доктринальний і нормативний обіг терміна «територіальний мікроколектив» для визначення кола осіб, інтереси яких представляє орган самоорганізації населення. На думку автора, територіальний мікроколектив - це поєднані відносно стійкими соціальними зв'язками жителі населеного пункту або його частини, межі якої не збігаються з межами діяльності будь-якого органу місцевого самоврядування. Для більш детального аналізу територіальних мікроколективів уявляється доцільним виділяти їхні види залежно від притаманних їм особливостей; узагальнена інформація про підстави класифікації територіальних мікроколективів та про їхні види наведено в таблиці 1.

За законодавством України, інтереси територіального мікроколективу можуть захищати, у разі їхнього створення, органи самоорганізації населення. Варто зауважити, що групування цих органів за різними підставами класифікацій сприятиме розвитку як законодавства, так і відповідних доктринальних досліджень. Вказані класифікації матимуть і високий рівень практичного значення - як для самих членів територіальних

Таблиця 1

\section{Класифікації територіальних мікроколективів}

\begin{tabular}{|c|c|c|}
\hline № & Підстава класифікації & Види територіальних мікроколективів \\
\hline 1 & $\begin{array}{l}\text { Кількість членів територі- } \\
\text { ального мікроколективу, } \\
\text { які мають право голосу } \\
\text { на місцевих виборах }\end{array}$ & $\begin{array}{l}\text { 1) невеликі територіальні мікроколективи (територіаль- } \\
\text { ний мікроколектив налічує не більш як } 150 \text { членів, які } \\
\text { мають право голосу на місцевих виборах); } \\
\text { 2) великі територіальні мікроколективи (територіаль- } \\
\text { ний мікроколектив налічує більш як } 150 \text { членів, які } \\
\text { мають право голосу на місцевих виборах). }\end{array}$ \\
\hline 2 & $\begin{array}{l}\text { Вид населеного пункту, } \\
\text { в межах якого існує тери- } \\
\text { торіальний мікроколектив }\end{array}$ & $\begin{array}{l}\text { 1) сільські територіальні мікроколективи; } \\
\text { 2) територіальні мікроколективи міської місцевості; } \\
\text { - селищні територіальні мікроколективи; } \\
\text { - міські територіальні мікроколективи. }\end{array}$ \\
\hline 3 & $\begin{array}{l}\text { Наявність або відсут- } \\
\text { ність у територіального } \\
\text { мікроколективу власних } \\
\text { легалізованих органів } \\
\text { (органів самоорганізації } \\
\text { населення) }\end{array}$ & $\begin{array}{l}\text { 1) територіальні мікроколективи, які мають свої легалі- } \\
\text { зовані органи (територіальні мікроколективи, які мають } \\
\text { органи самоорганізації населення); } \\
\text { 2) територіальні мікроколективи, які не мають своїх } \\
\text { легалізованих органів (територіальні мікроколективи, } \\
\text { які не мають органів самоорганізації населення). }\end{array}$ \\
\hline 4 & $\begin{array}{l}\text { Наявність або відсут- } \\
\text { ність у територіального } \\
\text { мікроколективу власних } \\
\text { постійно діючих органів }\end{array}$ & $\begin{array}{l}\text { 1) територіальні мікроколективи, які мають свої постій- } \\
\text { но діючі органи; } \\
\text { 2) територіальні мікроколективи, які не мають своїх } \\
\text { постійно діючих органів. }\end{array}$ \\
\hline
\end{tabular}


мікроколективів, так і для працівників органів місцевого самоврядування та органів державної влади, які безпосередньо взаємодіють з органами самоорганізації населення.

Насамперед звернемося до таблиці 1: деякі підстави класифікацій територіальних мікроколективів можуть бути використані і під час характеристики видів органів самоорганізації населення. Класифікація на підставі наявності або відсутності в територіального мікроколективу власних постійно діючих органів не може бути використана, адже ми розглядаємо тільки ті територіальні мікроколективи, які мають свої постійно діючі органи (якщо точніше - тільки ті територіальні мікроколективи, які мають свої органи самоорганізації населення). Також не $€$ прийнятною класифікація територіальних мікроколективів за ознакою наявності або відсутності у них власних легалізованих органів (тобто органів самоорганізації населення).

Що ж до класифікації територіальних мікроколективів залежно від виду населеного пункту, в межах якого існує територіальний мікроколектив, то вона є цілком доречною і коли йдеться про органи самоорганізації населення. Отже, доцільним уявляється класифікувати органи самоорганізації населення залежно від виду населеного пункту, в межах якого вони існують, на органи самоорганізації сільського населення та органи самоорганізації міського населення.

Органи самоорганізації міського населення щодо України уявляється доцільним поділити на органи самоорганізації населення селища та органи самоорганізації населення міста.

Нарешті, в таблиці 1 запропоновано класифікувати територіальні мікроколективи залежно від кількості членів територіального мікроколективу, які мають право голосу на місцевих виборах. Пропонуючи цю підставу для класифікації, авторка спиралася на те, що Закон України від 21 травня 1997 р. «Про місцеве самоврядування в Україні» передбачає таку форму безпосередньої участі членів територіальних колективів і територіальних мікроколективів у розв'язанні питань місцевого значення, як загальні збори громадян за місцем проживання - зібрання всіх чи частини жителів села (сіл), селища, міста для розв'язання питань місцевого значення [4]. Тим же Законом передбачено, що порядок проведення загальних зборів громадян за місцем проживання визначається законом (на сучасному етапі такого Закону України не прийнято, діє затверджене Постановою Верховної Ради України від 17 грудня 1993 р. Положення «Про загальні збори громадян за місцем проживання в Україні») і статутом територіальної громади. Застосовуючи норми чинного законодавства України за аналогією, доходимо висновку, що право брати участь у загальних зборах громадян $є$ одним із політичних прав, а отже, належить тільки громадянам України. Крім того, це політичне право стосується участі громадян України у здійсненні місцевого самоврядування, а отже, право брати участь у загальних зборах матимуть ті члени територіального мікроколективу (територіального колективу), які мають право голосу на місцевих виборах.

Доцільність цієї класифікації територіальних мікроколективів пов'язана 3 тим, що організація та проведення загальних зборів, у яких можуть узя- 
ти участь до 150 осіб, істотно відрізняється від організації та проведення загальних зборів для більшої кількості осіб; в останньому випадку більш ефективним може бути, наприклад, проведення зборів (конференції) представників членів територіального мікроколективу. 3 огляду на вищезазначене пропонувати таку підставу для класифікації органів самоорганізації населення не уявляється потрібним.

А ось класифікація залежно від кількості членів територіального мікроколективу, інтереси яких представляє орган самоорганізації населення, може бути ефективною. Адже цілком закономірним $є$ те, що орган самоорганізації населення, який представляє інтереси, наприклад, будинку, в якому проживає приблизно 100 осіб, матиме дещо інші цілі діяльності, повноваження, внутрішню структуру тощо, порівняно з органом самоорганізації мікрорайону, в якому мешкає приблизно 10000 осіб. Але такий вплив матиме не стільки статистична кількість членів територіального мікроколективу, скільки територія його існування. Отже, у підставі для класифікації буде йтись про «локалізацію», вид компактного місця проживання членів відповідного територіального мікроколективу - чи то будинок, чи то вулиця тощо. Такі пропозиції трапляються в доктринальній літературі. Наприклад, В.С. Кашо у статті «Законодавство про органи територіального громадського самоврядування: стан та перспективи розвитку» розглядає поділ органів територіального громадського самоврядування (на сучасному етапі в Україні - органи самоорганізації населення. - H. M.) на дві групи:

- органи територіального громадського самоврядування житлових масивів (ради або комітети мікрорайонів, житлових комплексів);

- інші органи самоврядування населення за місцем проживання (ради або комітети вулиць, кварталів, будинків) [5, с. 80].

У цитованій вище статті не надаються критерії житлових масивів і житлових комплексів, але зважаючи на зміст пропозиції думається, що поділ здійснюється за ознакою територіальної, просторової діяльності відповідних органів: будинок, вулиця, квартал, мікрорайон. Така підстава для класифікації уявляється важливою, але вона потребує подальшої конкретизації тому, що поділ тільки на дві вказані вище групи не окреслюватиме всі особливості функціонування органів самоорганізації населення. 3 огляду на це більш вдалою є пропозиція Б.М. Габрічідзе та O.K. Конєва, які пропонують виділяти такі групи комітетів громадян за місцем проживання (на сучасному етапі в Україні - органи самоорганізації населення. - Н. М.):

- будинкові;

- вуличні (квартальні);

- мікрорайонів міст [6, с. 6].

Але й ця класифікація може бути доповнена з урахуванням положень частини 3 статті 7 Закону України від 11 липня 2001 р. «Про органи самоорганізації населення», у якій надано перелік видів органів самоорганізації населення залежно від типу території, у межах якої діє такий орган. Йдеться про створення:

а) сільського, селищного комітету - у межах території села, селища, якщо його межі не збігаються з межами діяльності сільської, селищної ради; 
б) вуличного, квартального комітету - у межах території кварталу, кількох, однієї або частини вулиці з прилеглими провулками в місцях індивідуальної забудови;

в) комітету мікрорайону - у межах території окремого мікрорайону, житлово-експлуатаційної організації в містах;

г) будинкового комітету - у межах будинку (кількох будинків) в державному і громадському житловому фондах і фонді житлово-будівельних кооперативів;

г) комітету району в місті - у межах одного або кількох районів у місті, якщо його межі не збігаються з межами діяльності районної у місті ради.

3 урахуванням вищенаведених пропозицій уявляється доцільним виділяти такі види органів самоорганізації населення залежно від типу територіï, у межах якої діє такий орган:

1) у межах будинку - будинкові органи самоорганізації населення. Вони захищають інтереси членів територіальних мікроколективів багатоквартирного житлового будинку. Сфера діяльності цих органів буде передбачати переважно питання, пов'язані із забезпеченням життєдіяльності самого будинку - ремонт, прибирання приміщень суспільного користування всередині та поблизу будинку; контроль за якістю надаваних особам, які проживають у будинку, житлово-комунальних послуг та за якістю проведених у будинку ремонтних робіт, інші власні та делеговані повноваження;

2) у межах вулиці (кварталу) - вуличні (квартальні) органи самоорганізації населення. Більшість учених об'єднує ї в одну групу (див., напр., [7, с. 91; 6, с. 6]), адже і вуличні, і квартальні органи самоорганізації населення захищають інтереси членів територіальних мікроколективів одноквартирних і багатоквартирних житлових будинків, які розташовані:

або на вулиці (у населених пунктах вулиця - це територія між двома рядами будинків для руху транспорту та пішоходів, яка включає проїзну частину [8]);

- або на проспекті ((від лат. prospectus - огляд, панорама) - пряма, довга та широка вулиця в населеному пункті [8]);

- або у провулку;

- або у проїзді тощо;

- на одному кварталі ((від лат. quartus - четвертий); у градобудівництві квартал - це частина забудованої території населеного пункту, яка обмежена кількома вулицями, що пересікаються, передбачає цілісність архітектурного замислу та передбачає дотримання економічних, протипожежних і санітарно-гігієнічних вимог) [8].

Сфера діяльності органів самоорганізації населення вулиць (кварталів) буде більш широкою, ніж у тих органів самоорганізації населення, які представляють інтереси житлового будинку. До повноважень, які будуть здійснювати органи самоорганізації населення вулиць (кварталів), найімовірніше, належатимуть, поряд із нагальними проблемами мешканців окремих будинків, і питання, які стосуються всіх жителів вулиці (кварталу) - благоустрій, озеленення, пожежна безпека, ремонт шляхів, тротуарів, комунальних мереж, об'єктів загального користування тощо;

3) у межах мікрорайону, села, селища, району у місті: 
- органи самоорганізації населення мікрорайонів - вони захищають інтереси членів територіальних мікроколективів одноквартирних і багатоквартирних житлових будинків, які розташовані на території кількох кварталів. Мікрорайоном уважається структурно-планувальна одиниця поділу території населеного пункту, яка складається з житлових будинків та установ обслуговування [8]. Мікрорайони є первинними територіальними складовими частинами міських поселень, просторовою базою цілого комплексу служб [9, с. 447], адже вони «об’єднують житловий квартал чи робоче селище, які мають своєрідний центр із закладами культури, охорони здоров'я, школами, підприємствами торгівлі, побуту, комунального обслуговування» [10, с. 4];

- органи самоорганізації населення села, селища, району у місті (район у місті створюють декілька мікрорайонів; він «обслуговується комплексом культурно-побутових установ і включає систему озеленення» [8]). Як згадувалось вище, у разі, якщо йдеться про орган самоорганізації населення села, селища або району у місті, територія його діяльності не повинна збігатися з територією діяльності відповідної ради.

Отже, сфера діяльності органів самоорганізації населення мікрорайонів, сіл, селищ і районів у місті буде більш широкою, ніж у органів самоорганізації населення, які представляють інтереси членів територіальних мікроколективів, об’єднаних проживанням у межах однієї або кількох вулиць чи кварталу, через те, що до їхньої сфери інтересів, крім житлових будинків, завжди потраплятимуть і культурно-побутові та інші установи, які обслуговують мешканців відповідних територій.

Враховуючи вищезазначене, пропонується класифікувати територіальні мікроколективи залежно від типу території проживання членів територіального мікроколективу й виділяти:

- територіальні мікроколективи будинків;

- територіальні мікроколективи вулиць і кварталів;

- територіальні мікроколективи мікрорайонів і територіальні мікроколективи села, селища, району у місті - якщо територія проживання членів цих мікроколективів не збігається з територією діяльності відповідної ради.

Аналіз інших положень Закону України від 11 липня 2001 р. «Про органи самоорганізації населення» дає змогу групувати органи самоорганізації населення:

- за наявністю або відсутністю у них ознак юридичної особи: на органи самоорганізації населення, які легалізовані шляхом реєстрації (є юридичними особами), та на органи самоорганізації населення, які легалізовані шляхом повідомлення (не є юридичними особами);

- за наявністю або відсутністю в органа самоорганізації населення повноважень, делегованих відповідною місцевою радою: на органи самоорганізації населення, яким відповідна місцева рада делегувала деякі зі своїх власних повноважень, та на органи самоорганізації населення, які здійснюють виключно повноваження, надані їм Законом України «Про органи самоорганізації населення».

Варто підкреслити, що є різні думки щодо співвідношення понять «типологія» та «класифікація». Слід підтримати ту з них, яка пропонує вважати 
Таблиця 2

Класифікації органів самоорганізації населення

\begin{tabular}{|c|c|c|}
\hline № & Підстава класифікації & Види органів самоорганізації населення \\
\hline 1 & $\begin{array}{c}\text { Вид населеного пункту, } \\
\text { в межах якого функціону- } \\
\text { ють органи самоорганізації } \\
\text { населення }\end{array}$ & $\begin{array}{l}\text { 1) органи самоорганізації сільського населення; } \\
\text { 2) органи самоорганізації міського населення: } \\
\text { - органи самоорганізації населення селища; } \\
\text { - органи самоорганізації населення міста. }\end{array}$ \\
\hline 2 & $\begin{array}{l}\text { Наявність або відсутність } \\
\text { в органа самоорганізації насе- } \\
\text { лення повноважень, } \\
\text { делегованих відповідною } \\
\text { місцевою радою }\end{array}$ & $\begin{array}{l}\text { 1) органи самоорганізації населення, яким відповід- } \\
\text { на місцева рада делегувала деякі зі своїх власних } \\
\text { повноважень; } \\
\text { 2) органи самоорганізації населення, які здійснюють } \\
\text { виключно повноваження, надані їм Законом України } \\
\text { «ро органи самоорганізації населення». }\end{array}$ \\
\hline 3 & $\begin{array}{c}\text { Наявність або відсутність } \\
\text { в органу самоорганізації } \\
\text { населення ознак юридичної } \\
\text { особи (або залежно від виду } \\
\text { легалізації) }\end{array}$ & $\begin{array}{l}\text { 1) органи самоорганізації населення, які легалізова- } \\
\text { ні шляхом реєстрації (є юридичними особами); } \\
\text { 2) органи самоорганізації населення, які легалізовані } \\
\text { шляхом повідомлення (не є юридичними особами). }\end{array}$ \\
\hline
\end{tabular}

типологією найбільш важливу класифікацію з числа наявних. На нашу думку, типологія органів самоорганізації населення має проводитись залежно від виду території, у межах якої діє орган самоорганізації населення.

Узагальнену інформацію про підстави класифікації органів самоорганізації населення та про їхні види наведено в таблиці 2.

Висновки з дослідження. В Україні органи самоорганізації населення представляють і захищають інтереси членів територіальних мікроколективів. Для підвищення ефективності функціонування та поглибленого вивчення цих органів уявляється доцільним поділяти їх на види за їхніми характерними рисами. У статті пропонується здійснювати типологію органів самоорганізації населення залежно від території, у межах якої діє орган самоорганізації населення. Автором запропоновано проводити класифікацію органів самоорганізації населення на підставах: 1) виду населеного пункту, в межах якого функціонують органи самоорганізації населення; 2) наявності або відсутності в органу самоорганізації населення повноважень, делегованих відповідною місцевою радою; 3) наявності або відсутності в органу самоорганізації населення ознак юридичної особи (або залежно від виду легалізаціі).

Перспективи подальших розвідок у цьому напрямі вбачаються в доцільності вивчення особливостей кожного з видів органів самоорганізації населення. Це надасть можливість підвищити ефективність їхнього функціонування та ефективність представництва інтересів членів територіальних мікроколективів.

\section{Література}

1. Мішина Н.В. Муніципальна реформа в Україні: стан і перспективи. Право України. 2018. № 4. C. 126-138.

2. Мішина Н.В. Конституційна регламентація місцевого самоврядування в Україні: сучасність та перспективи. Публічне право. 2015. № 3. С. 67-72.

3. Мішина Н.В. Законопроекти для розвитку локальної демократії в Україні. Юридичний вісник. 2014. № 2. С. 36-40. 
4. Про місцеве самоврядування в Україні : Закон України від 21 травня 1997 р. Biдомості Верховної Ради України. 1997. № 24. Ст. 170.

5. Кашо В.С. Законодательство об органах территориального общественного самоуправления: состояние и перспективы развития. Правоведение. 1991. № 5. С. 77-81.

6. Габричидзе Б.Н., Конев А.К. Уличные (квартальные) комитеты. Москва : Издательство «Юридическая литература», 1965. 71 с.

7. Формы участия общественности в работе местных советов депутатов трудящихся. Москва : Государственное издательство юридической литературы, 1963. 216 с.

8. Тлумачний словник української мови. URL: https:/ / slovnyk.ua.

9. Барабашев Г.В., Шеремет К.Ф. Советское строительство : учебник. Москва : Юридическая литература, 1988. 560с.

10. Общественные советы микрорайонов. Опыт, инициатива, поиски. Донецк : Издательство «Донбасс», 1971. 80 с.

\section{Ано т а ц і я \\ Мiшина H. B. Органи самоорганізації населення в Україні: типологія та класифі- кація. - Стаття.}

Територіальний мікроколектив - це з'єднані відносно стійкими соціальними зв'язками жителі населеного пункту або його частини, межі якої не збігаються з межами діяльності будь-якого органу місцевого самоврядування. Паралельне дослідження територіальних мікроколективів та органів самоорганізації населення дає змогу запропонувати класифікувати територіальні мікроколективи залежно від типу території проживання членів територіального мікроколективу на: територіальні мікроколективи будинків, територіальні мікроколективи вулиць та кварталів і територіальні мікроколективи мікрорайонів, а також територіальні колективи села, селища, району у місті - якщо територія локалізації таких територіальних мікроколективів не збігається з територією діяльності відповідної ради.

Автор статті вважає, що типологізація являє собою класифікацію за найбільш важливою підставою. Запропоновано здійснювати типологізацію органів місцевого самоврядування залежно від території, у межах якої діє орган самоорганізації населення: на будинкові органи самоорганізації населення, вуличні (квартальні) органи самоорганізації населення й органи самоорганізації населення мікрорайону, села, селища, району у місті (у разі, якщо йдеться про орган самоорганізації населення села, селища або району у місті, територія його діяльності не повинна збігатися з територією діяльності відповідної ради).

Деякі підстави, які використовуються для класифікації територіальних мікроколективів, уявляється доцільним використати і для класифікації органів, що створюються для захисту інтересів цих колективів, - органів самоорганізації населення. Крім того, у статті наводяться й інші, не пов’язані з видами територіальних мікроколективів, підстави для класифікацій органів самоорганізації населення. Загалом, органи самоорганізації населення пропонується класифікувати:

- залежно від виду населеного пункту, в межах якого функціонують органи самоорганізації населення: на органи самоорганізації сільського населення й органи самоорганізації міського населення (органи самоорганізації населення селищ та органи самоорганізації населення міст);

- залежно від наявності або відсутності в органу самоорганізації населення ознак юридичної особи: на органи самоорганізації населення, які легалізовані шляхом реєстрації (є юридичними особами), та на органи самоорганізації населення, які легалізовані шляхом повідомлення (не є юридичними особами);

- залежно від наявності або відсутності в органу самоорганізації населення повноважень, делегованих відповідною місцевою радою: на органи самоорганізації населення, яким відповідна місцева рада делегувала деякі зі своїх власних повноважень, і органи самоорганізації населення, які здійснюють виключно повноваження, надані їм Законом України «Про органи самоорганізації населення».

Ключові слова: будинкові комітети, місцеве самоврядування, муніципальне управління, самоорганізація населення, населення, територіальна громада. 


\section{S u m m a r y \\ Mishyna N. V. Organs of self-organization of the population: typology and classifica- tion. - Article.}

Territorial micro-collective is a population of a settlement or a part thereof connected by relatively stable social links, the boundaries of which do not coincide with the boundaries of the activity of any local self-government body. The parallel study of territorial micro-collectives and self-organization bodies suggests to classify territorial micro-collectives according to the type of local residence of members of a territorial micro-collective into territorial micro-collectives of buildings, territorial micro-collectives of streets and neighborhoods and territories such territorial micro-collectives do not coincide with the territory of the municipal council.

Typology in this article is seen as the most important classification. Bodies of self-organization of the population may be typologized depending on the local territory within which the body operates (body of self-organization of the population of a village, settlement or district in a city, the territory of its activity should not coincide with the territory of activity of the municipal council).

It seems appropriate to use some grounds used for the classification of territorial micro-collectives, for the classification of bodies that are created to protect the interests of these collectives - bodies of self-organization of the population. In addition, the article provides other grounds for classifications of self-organization bodies not related to the types of territorial micro-collectives. In general, self-organization bodies are proposed to classify:

depending on the type of settlement within which the self-organization bodies of the population function: on self-organization bodies of rural population and self-organization bodies of urban population (self-organization bodies of settlements and self-organization bodies of cities);

depending on the presence or absence from the body of self-organization of the population of the signs of a legal entity: on self-organization of the population, which are legalized by registration (are legal entities), and on self-organization of the population, which are legalized by notification (not legal entities);

depending on the presence or absence from the body of self-organization of the population of powers delegated by the respective local council, "On bodies of self-organization of the population".

Key words: house committees, local government, municipal government, population self-organization, population, territorial community. 